\title{
Diurnal aerosol variations do affect daily averaged radiative forcing under heavy aerosol loading observed in Hefei, China
}

\author{
Z. Wang ${ }^{1}$, D. Liu ${ }^{1}$, Y. Wang ${ }^{1,2}$, Z. Wang ${ }^{1,3}$, and G. Shi ${ }^{4}$ \\ ${ }^{1}$ Key Laboratory of Atmospheric Composition and Optical Radiation, Anhui Institute of Optics and Fine Mechanics, \\ Chinese Academy of Sciences, Hefei, China \\ ${ }^{2}$ University of Science and Technology of China, Hefei, China \\ ${ }^{3}$ Department of Atmospheric Science, University of Wyoming, Laramie, Wyoming, USA \\ ${ }^{4}$ Institute of Atmospheric Physics, Chinese Academy of Sciences, Beijing, China \\ Correspondence to: Z. Wang (zzwang@aiofm.ac.cn) and D. Liu (dliu@aiofm.ac.cn)
}

Received: 27 January 2015 - Published in Atmos. Meas. Tech. Discuss.: 23 February 2015

Revised: 01 July 2015 - Accepted: 02 July 2015 - Published: 20 July 2015

\begin{abstract}
A strong diurnal variation of aerosol has been observed in many heavily polluted regions in China. This variation could affect the direct aerosol radiative forcing (DARF) evaluation if the daily averaged value is used as normal rather than the time-resolved values. To quantify the effect of using the daily averaged DARF, 196 days of high temporal resolution ground-based data collected in SKYNET Hefei site during the period from 2007 to 2013 is used to perform an assessment. We demonstrate that strong diurnal changes of heavy aerosol loading have an impact on the 24-h averaged DARF when daily averaged optical properties are used to retrieve this quantity. The DARF errors varying from -7.6 to $15.6 \mathrm{~W} \mathrm{~m}^{-2}$ absolutely and from 0.1 to $28.5 \%$ relatively were found between the calculations using daily average aerosol properties, and those using time-resolved aerosol observations. These errors increase with increasing daily aerosol optical depth (AOD) and decreasing daily singlescattering albedo (SSA), indicating that the high temporal resolution DARF data set should be used in the model instead of the normal daily-averaged one, especially under heavy aerosol loading conditions for regional campaign studies. We also found that statistical errors $\left(0.3 \mathrm{~W} \mathrm{~m}^{-2}\right.$ absolutely and $11.8 \%$ relatively) will be less, which means that the effect of using the daily averaged DARF can be weakened by using a long-term observational data set.
\end{abstract}

\section{Introduction}

The direct aerosol radiative effect (DARF) is defined as the change in radiative flux caused by the combined scattering and absorption of radiation by a variety of aerosols. The DARF can be well estimated through the well-developed model and inputs from the observations regionally, such as daily estimates of aerosol optical properties (AOP), i.e., aerosol optical depth (AOD), single-scattering albedo (SSA), and asymmetry factor (ASY). These AOP could be obtained from ground-based observations, such as the Aerosol Robotic Network (AERONET) (Holben et al., 1998), Sky Radiometer Network (SKYNET) (Nakajima et al., 2003), China Aerosol Remote Sensing Network (CARSNET) (Che et al., 2009) . In the assessment report of IPCC (2013), the scientific understanding of DARF has been designated as High. However, DARF can reach tens of $\mathrm{W} \mathrm{m}^{-2}$ locally. Estimates of DARF regionally still contain significant uncertainties due to complex aerosol sources, strong diurnal variability, and poorly known morphology. Strong diurnal variations of AOP have been observed in many regions, especially in some heavily polluted regions, such as in Xianghe (Li et al., 2007), Taihu (Xia et al., 2007), Beijing (Che et al., 2014), and Hefei (Wang et al., 2014) China. The diurnal variations of AOP could dramatically affect aerosol radiative forcing calculations (Christopher et al., 2003) and result in significant biases especially in regional ADRF estimations (Arola et al., 2013). However, the uneven high temporal sampling of aerosol properties from the surface may be unable to faith- 
fully recover the diurnal changes of aerosol optical properties due to cloudy cover or invalid retrievals. Therefore, it has been commonly assumed that the aerosol optical properties are constant and daily averaged values are normally used to calculate 24-h averaged DARF on regional scales. The influence should be investigated in detail especially for some polluted regions with heavy aerosol loading and strong diurnal variations of AOP.

\section{Data and methods}

To investigate this problem, the aerosol data observed at the SKYNET Hefei super site (Nakajima et al., 2007; Zhou et al., 2002) was used, where a sky-radiometer, a microwave radiometer, and a set of broadband radiometers have been operated continuously for aerosol-radiation measurements since the end of 1997. The site is influenced by local urban or rural aerosols depending on wind direction with high aerosol loading throughout the year. The annual mean $500 \mathrm{~nm}$ AOD at this site is as high as 0.84 (Wang et al., 2014). Therefore, a strong diurnal variability of AOP is expected at the site. The Prede POM-02 sky-radiometer measures the direct and diffuse solar radiations every $10 \mathrm{~min}$ in the daytime, which is an advantage with high temporal resolution measurement to cover all variations of AOP throughout day. This skyradiometer has seven aerosol channels with wavelengths of $340,380,400,500,675,870$, and $1020 \mathrm{~nm}$, which are used to retrieve AOP with the SKYRAD retrieval package (Nakajima et al., 1996). This sky-radiometer can be calibrated on-site to derive the calibration constant $(F 0)$ using the improved Langley method (Campanelli et al., 2004). After cloud screening using the algorithm of Khatri et al. (2009), the spectral values of $\operatorname{AOD}(\tau), \operatorname{SSA}(\omega)$ and $\operatorname{ASY}(g)$ are determined during the period from 2007 to 2013 . There are $196 \mathrm{com}$ pletely cloud-free days with high temporal measurements and retrievals, comprising the data set used in this study. The derived aerosol properties ( $\tau, \omega$ and $g$ ) are used as key input parameters to calculate surface solar radiations based on the Santa Barbara Discrete-ordinate Atmospheric Radiative Transfer (SBDART) model (Ricchiazzi et al., 1998), which was verified with surface broadband spectrum irradiance observations (Halthore et al., 2005). The complementary parameters (columnar water vapor content, total ozone amount, and spectral surface albedo) used to run the model are retrieved from the surface microwave radiometer (Model WVR-1100, Radiometrics Corporation, USA) (Westwater et al., 1978; Ulaby et al., 1986), the Ozone Monitoring Instrument (OMI) data sets (McPeters et al., 2008), and the Moderate Resolution Imaging Spectroradiometer (MODIS) products (Schaaf et al., 2011), respectively.

To estimate the sensitivity of 24-h averaged DARF to the diurnal changes of aerosol optical properties, we perform the DARF (named, $F$ ) at the surface (named, SFC) calculations with different conditions on the daily $\mathrm{AOP}(\tau, \omega$ and $g$ ) vari-

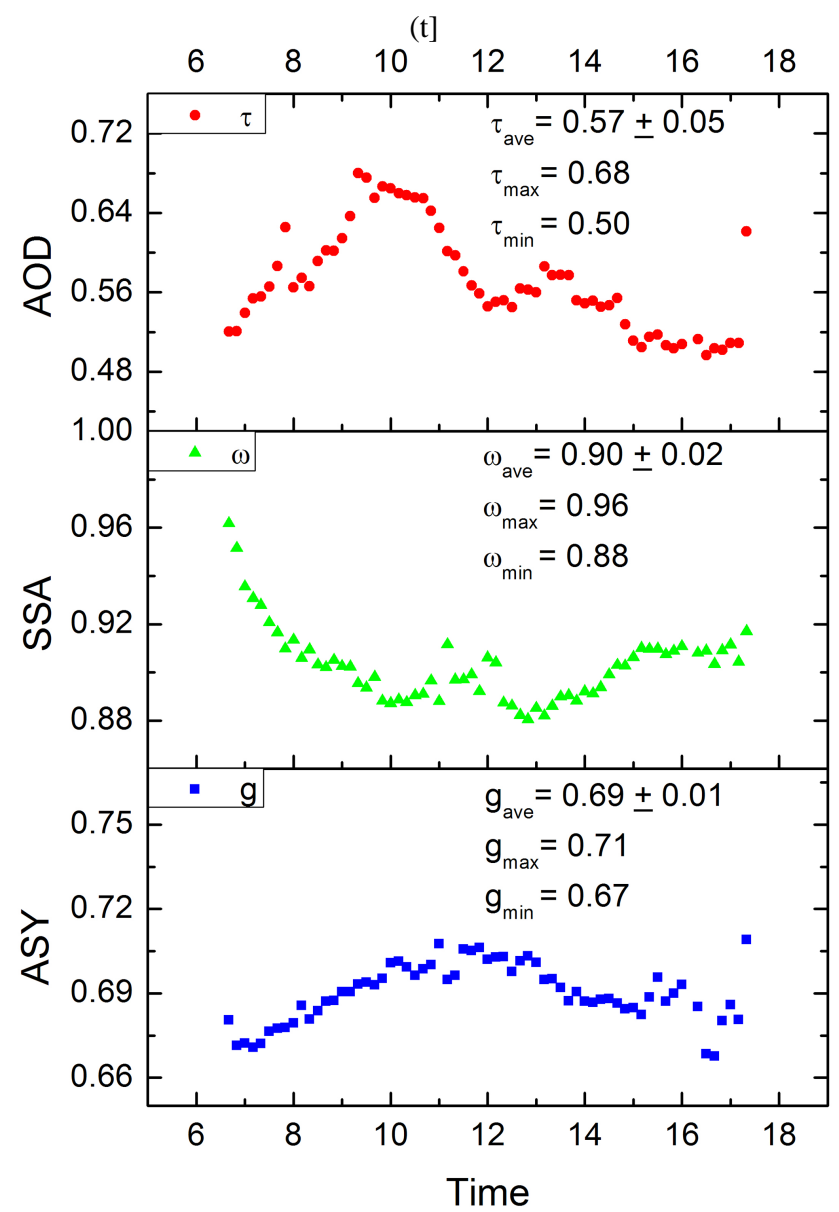

Figure 1. Daily variations of retrieved $500 \mathrm{~nm}$ AOD (red), SSA (green) and ASY (blue) on 14 April 2013. This represents a typical light polluted case (mean AOD of 0.57 ) with moderate diurnal changes of AOP.

ation in two ways: (1) diurnally varying AOP according to entire time-dependent observations, $\mathrm{AOP}=$ actual changes of AOP; (2) no diurnally AOP variation but measurementbased, $\mathrm{AOP}=$ corresponding daily averaged AOP. Then we use these two sets of the AOP (the original high temporal resolution data set, which covers the complete diurnal variation, plus the additional synthetic set) and the other complementary parameters as input for the SBDART model to calculate the diurnal changes of the DARF (named, $<F_{\text {org }}>$ related to time-resolved data set and $<F_{\text {ave }}>$ related to averaged data set). These DARF values at the surface are given in half hour intervals, from which we calculate the corresponding 24-h averaged DARF $(<F>)$. Thus, we obtain two sets of values of $\langle F\rangle$, which represent radiative forcings obtained from the original and daily averaged AOP. Furthermore, the absolute and relative errors of 24-h averaged DARF will be found as $\left\langle\delta F>\right.$ (i.e., $<F_{\text {ave }}>-<F_{\text {org }}>$ ) and $\operatorname{abs}\left(\frac{\delta F}{<F_{\text {org }}>}\right)$, respectively. These errors are used to assess quantitatively 


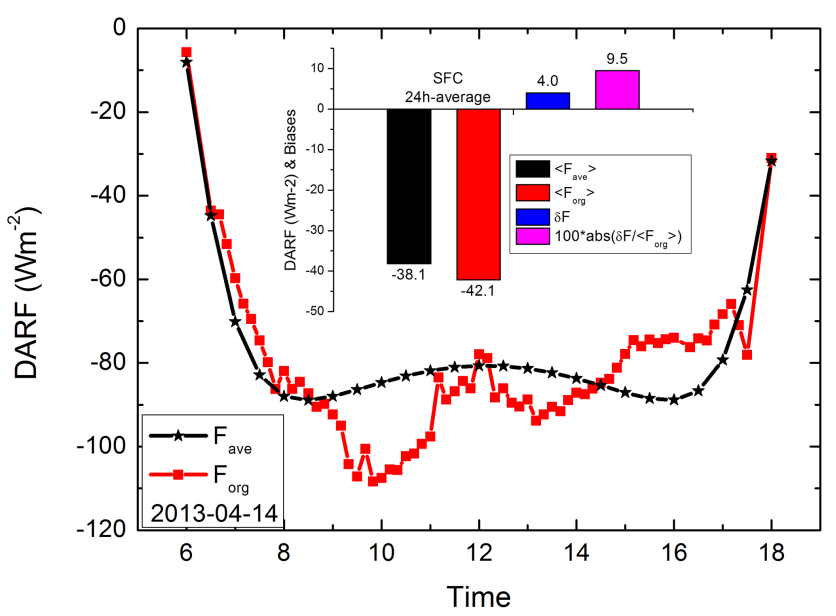

Figure 2. The corresponding instantaneous DARF values using the original (red) and daily averaged (black) AOP in Fig. 1, the 24-h average $F$ values with the absolute (blue) and relative biases (magenta) are included as well in the inset.

the effect of aerosol daily averaged radiative forcing due to diurnal variation.

\section{Results and discussion}

We applied our method to two typical kinds of cloud free cases observed at the SKYNET Hefei site on 14 April 2013 (CASE-I) and 12 February 2008 (CASE-II). The first case is a lightly polluted day, when diurnal changes of aerosol loading are moderate ranging from -12 to $19 \%$ on AOD as shown in Fig. 1. The daily averaged AOD value of CASE-I is 0.57 with a maximum 0.68 and a minimum 0.50 . On the contrary, the SSA and ASY are not changing so much with 0.90 (varying from 0.88 to 0.96 ) and 0.69 (varying from 0.67 to 0.71 ) on average, respectively. Thus, we will strongly consider AOD variability in the following discussions.

Using the original and daily averaged AOP for CASE-I as input parameter, the corresponding instantaneous DARF values are calculated with large differences as indicated in Fig. 2. For example, large overestimation $\left(23 \mathrm{~W} \mathrm{~m}^{-2}\right.$ in absolute value and $21 \%$ in relative value) at 10:00 and large underestimation $\left(15 \mathrm{~W} \mathrm{~m}^{-2}\right.$ in absolute value and $20 \%$ in relative value) at 16:00 of instantaneous DARF ( $F_{\text {ave }}$ versus $F_{\text {org }}$ ) are produced by AOP variability. It is noted that this overestimation and/or underestimation of instantaneous DARF may be compensated partially by each other when being used for estimating 24-h averaged $F$. The 24-h average $F$ values are $-38.1 \mathrm{~W} \mathrm{~m}^{-2}\left(<F_{\text {ave }}>\right)$ and $-42.1 \mathrm{~W} \mathrm{~m}^{-2}(<$ $\left.F_{\text {org }}>\right)$ with the absolute $\left(4.0 \mathrm{~W} \mathrm{~m}^{-2}\right)$ and relative $(9.5 \%)$ biases are shown as well in the inset of Fig. 2. As a result of CASE-I, the impact of the daily averaged aerosol properties on the 24-h average DARF may not be negligible after

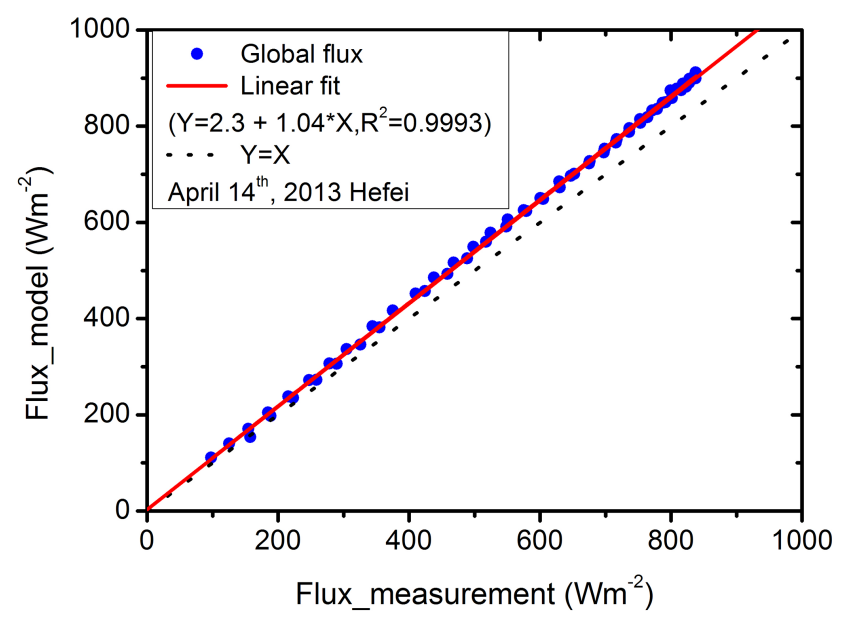

Figure 3. Comparisons between the SBDART simulated and the measured fluxes of downward shortwave radiations at the surface in Hefei site on 14 April 2013.

integration of instantaneous DARF values over all daytime hours.

Note that we did not have AOP measurements to cover low solar zenith angles for calculation of $F_{\text {org }}$, where real measured flux (with aerosol) and calculated flux (without aerosol) are used to fill up data before the sunrise and after the sunset. Figure 3 has performed excellent shortwave radiative closure experiment using the accurate input parameters from SKYNET AOP measurements and high precision surface radiation fluxes by Kipp \& Zonen CM21.

Another case is chosen during a highly polluted day, when diurnal changes of aerosol loading are large ranging from -18 to $32 \%$ on AOD as shown in Fig. 4. The daily averaged AOD value of CASE-II is 1.08 , which is almost two times that of CASE-I with a maximum of 1.43 and a minimum of 0.89. Meanwhile, the SSA and ASY are 0.96 (varying from 0.94 to 0.97 ) and 0.69 (varying from 0.68 to 0.72 ) on average, respectively, with a slight changing as CASE-I. So, we will also consider AOD variability. Figure 5 shows the corresponding instantaneous DARF values using the original and daily averaged AOP in Fig. 4, which also produces large biases. The largest overestimation part of instantaneous DARF ( $F_{\text {ave }}$ versus $F_{\text {org }}$ ) is $24 \mathrm{~W} \mathrm{~m}^{-2}$ in absolute value and $17 \%$ in relative value and the largest underestimation counterpart is $16 \mathrm{~W} \mathrm{~m}^{-2}$ in absolute value and $15 \%$ in relative value due to AOD variability. But the 24-h average $F$ values are $-41.9 \mathrm{~W} \mathrm{~m}^{-2}\left(<F_{\text {ave }}>\right)$ and $-49.5 \mathrm{~W} \mathrm{~m}^{-2}\left(<F_{\text {org }}>\right)$ with the absolute $\left(7.5 \mathrm{~W} \mathrm{~m}^{-2}\right)$ and relative $(15.2 \%)$ biases, which are larger than those in CASE-I.

Figure 6 shows a comparison between the SBDART simulated and the measured fluxes of downward shortwave radiations at the surface in Hefei site on 12 February 2008, which indicates a good agreement with a high correlation coefficient 0.9945 . So, we can use measured data to fill up $F_{\text {org }}$ 


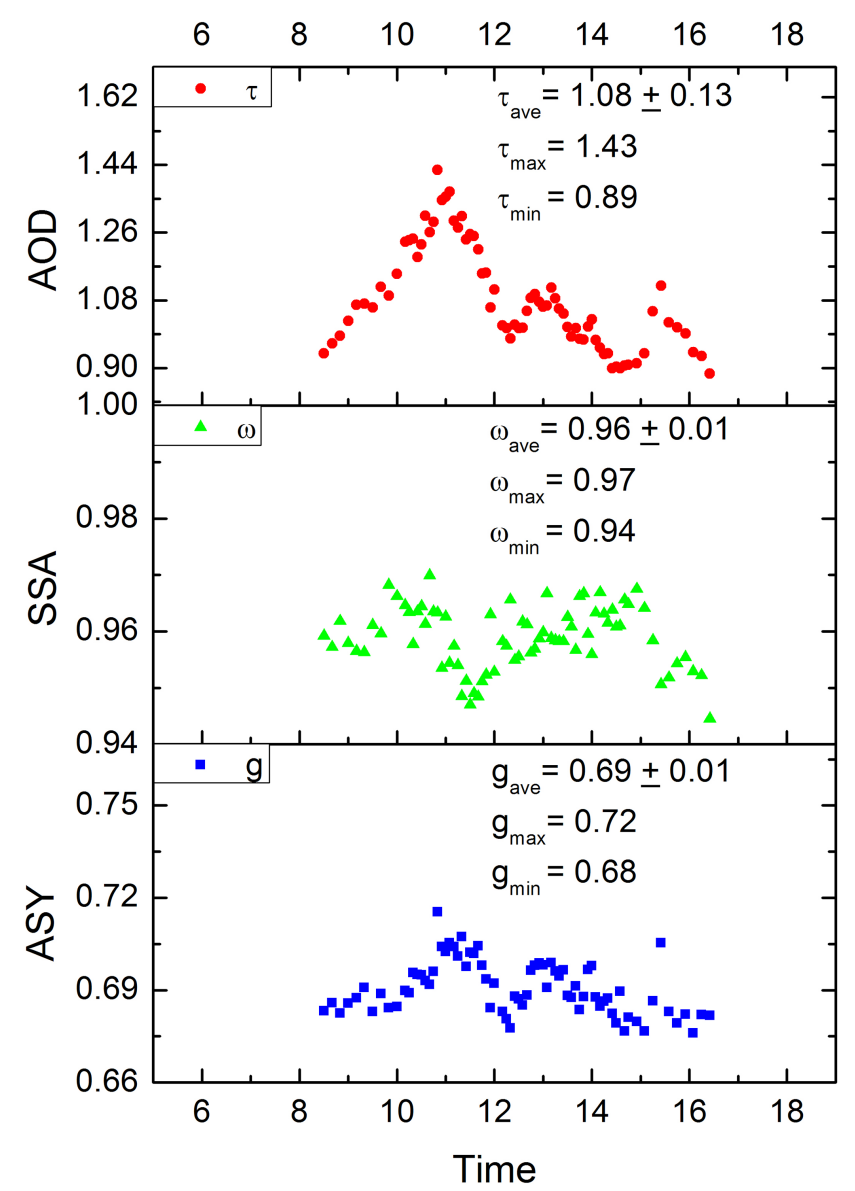

Figure 4. The same as Fig. 1 but for a day with large diurnal changes of aerosol loading under highly polluted (AOD equals to 1.08 in average) weather conditions on 12 February 2008.

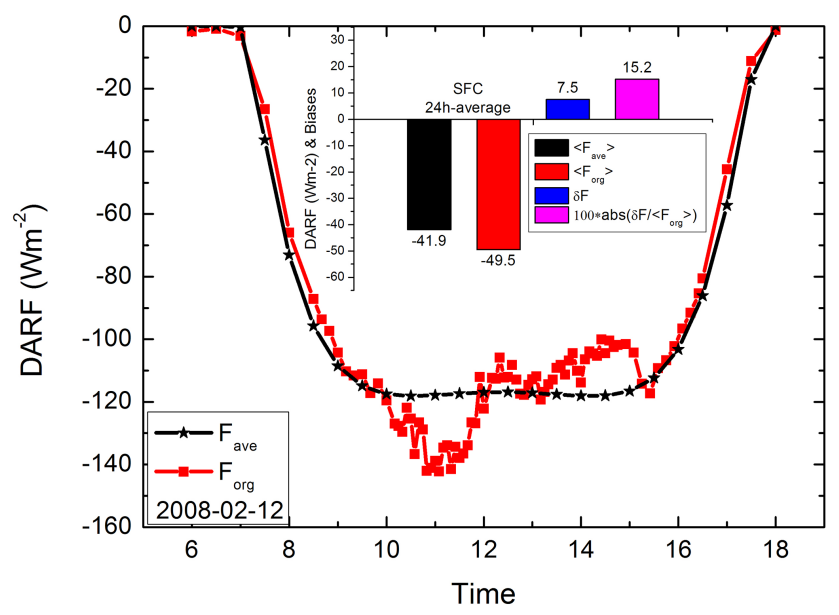

Figure 5. The same as Fig. 2 but using the AOP in Fig. 4.

values during the missing periods, which are also examined in Fig. 3.

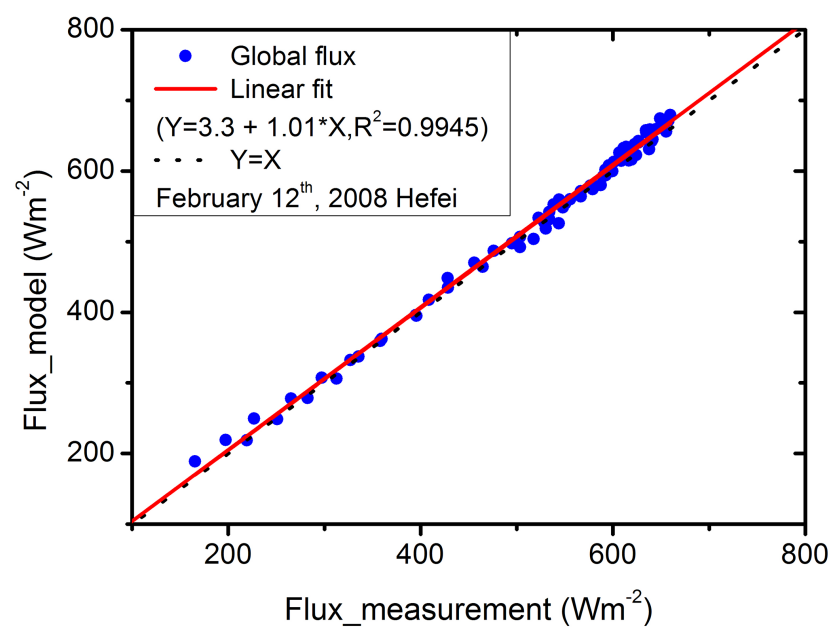

Figure 6. The same as Fig. 3 but in 12 February 2008.

Thus, an important result related to aerosol loading issue can be drawn from the two cases. The strong diurnal changes of heavy aerosol loading in SKYNET Hefei site have a considerable impact on the 24-h averaged $F$ value if daily averaged AOP is used to retrieve this quantity.

Let us consider the impact of daily averaged AOP on $F$ value for all selected 196 days, where high temporal resolution AOP is obtained throughout the day. Figure 7 shows the frequency distributions of daily mean AOD, SSA, and $\mathrm{ASY}$ at $500 \mathrm{~nm}$, the corresponding absolute and relative biases for 24-h average $F$ calculation in SKYNET Hefei site from 2007 to 2013. From these 196 cloud-free days, the aerosol loading covers clean clear day and heavily polluted day with daily averaged AOD ranging from 0.14 to 1.88 . Large day-to-day variability of AOD is also found from Fig. $7 \mathrm{a}$ with an averaged AOD $0.63 \pm 0.29$ except for the large diurnal difference discussed before. In Fig. 7b and 7c, the daily averaged SSA and ASY are also shown with light variations ranging from 0.85 to 0.99 and from 0.61 to 0.73 , respectively. As a sequence, the absolute and relative biases for 24-h average $F$ calculation are $0.3 \pm 4.2 \mathrm{~W} \mathrm{~m}^{-2}$ (varying from -7.6 to $15.6 \mathrm{~W} \mathrm{~m}^{-2}$ ) and $11.8 \% \pm 6.6 \%$ (varying from 0.1 to $28.5 \%$ ), respectively. That means the impact is significant and cannot be neglected for each day considered here. However, this kind of impact can be weakened through longterm high temporal resolution measurements. These findings are different from the others in some regions, where the observed conditions without heavy aerosol loading (AOD less than 0.4 ) are prevalent from other studies (Kassianov et al., 2013).

The relationship between DARF at SFC and AOD is examined and high correlation (0.82 and 0.71) has been found between AOD and 24-h average $F_{\text {ave }}$ and $F_{\text {org }}$, respectively. At the same time, there is an increasing trend of absolute biases $(\delta F)$ for 24-h average $F$ calculation with increasing daily mean $\operatorname{AOD}(\tau)$ at $500 \mathrm{~nm}$, and a large scattering in 


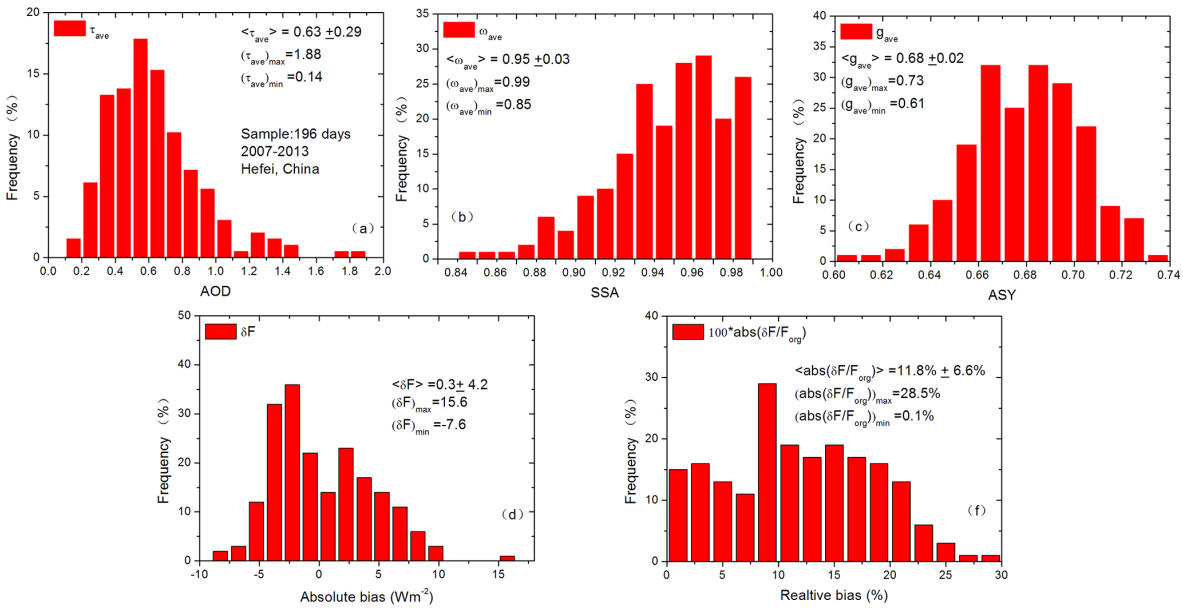

Figure 7. The frequency distributions of $\tau_{\mathrm{ave}}, \omega_{\mathrm{ave}}, g_{\text {ave }}, \delta F$, and $100 \cdot \operatorname{abs}\left(\frac{\delta F}{F_{\text {org }}}\right)$ selected in SKYNET Hefei site from 2007 to 2013.

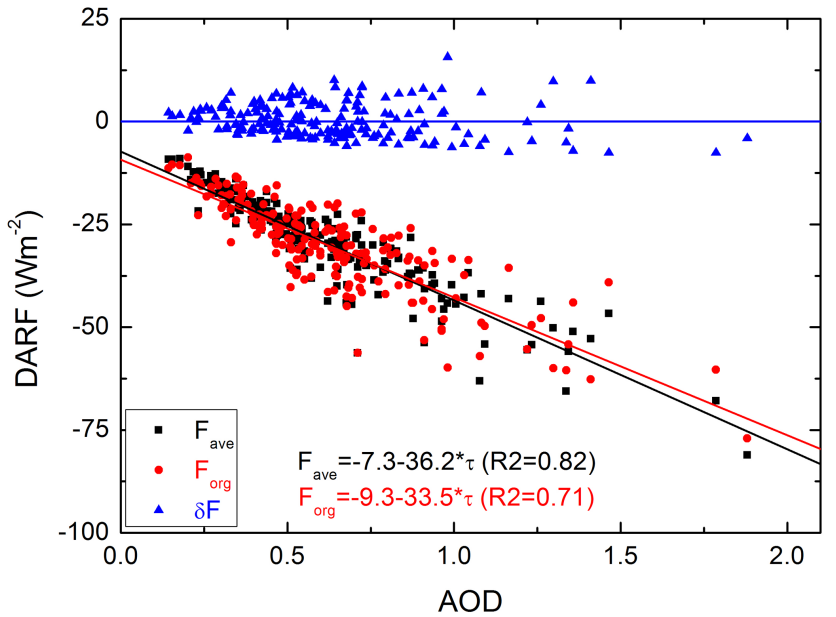

Figure 8. Correlations between aerosol forcing at the surface and $\mathrm{AOD}$ at $500 \mathrm{~nm}\left(F_{\text {ave }}\right.$ : black; $F_{\text {org }}$ : red; $\delta F$ : blue $)$ with linear fitting equations.

data points is related to high AOD as well (Fig. 8). Then Figs. 9 and 10 give the relationship between DARF at SFC and the other two parameters (i.e., SSA and ASY). Only to find that there is also an increase trend of $\delta F$ for 24-h average $F$ calculation with decreasing daily mean $\operatorname{SSA}(\omega)$ at $500 \mathrm{~nm}$, which means the more absorption of aerosol, the more contribution to the absolute biases. The phenomena in Figs. 8-10 indicate as follows: (1) the AOD with strong diurnal variation is more contributed to the corresponding 24-h averaged $F$ than SSA and ASY with weak temporal changes; (2) the well-established fact that the instantaneous DARF at SFC is linearly proportional to AOD (McComiskey et al., 2008 ) is also related to the highly polluted area (Li et al., 2010); (3) the extremely high biases for 24-h averaged $F$ are produced by a strong diurnal variation of AOD, variation of aerosol absorption property and/or high aerosol loading. Be-

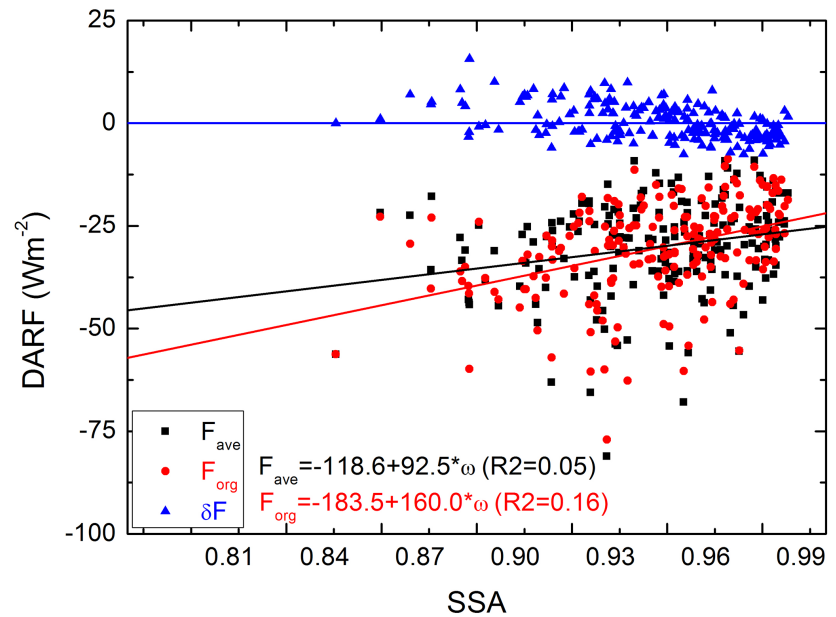

Figure 9. The same as the Fig. 8 but for SSA at $500 \mathrm{~nm}$.

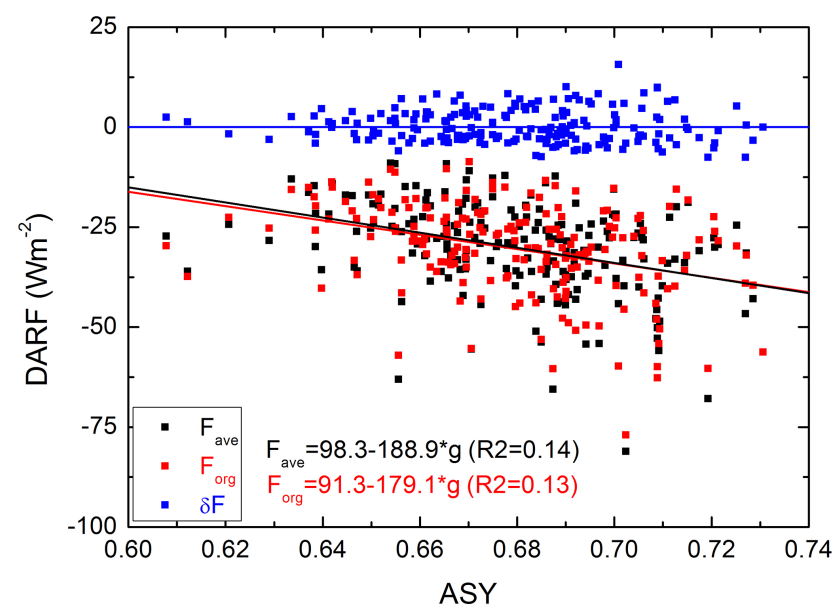

Figure 10. The same as the Fig. 8 but for ASY at $500 \mathrm{~nm}$. 
cause the observed conditions mentioned in this study are prevalent in many climatologically important regions with frequent heavy aerosol loadings, such as Xianghe (Li et al., 2007), Taihu (Xia et al., 2007), and Beijing (Che et al., 2014), the daily average radiative forcing calculation requires not only daily averaged optical properties, but also diurnal changes. Thus, in order to obtain accurate radiative transfer calculations in a high pollution region, the observation-based long-term high temporal aerosol data must be considered.

\section{Summary}

We assess the impact of the strong diurnal changes of aerosol on the 24-h average DARF at the surface using ground-based high temporal resolution sky-radiometer data in SKYNET Hefei site, China, during 196 cloud-free days from 2007 to 2013. The assessment evaluates the temporal variability of AOP, such as AOD, SSA, and ASY, and estimates the errors of this variability in determining DARF averaged over 24-h. To perform such an assessment, we retrieve observed high temporal resolution optical properties and their daily averaged ones as input for the SBDART model, and compare the 24-h average DARF calculated for these inputs.

The impact of the daily averaged aerosol properties on the 24-h average DARF can be up to $7.5 \mathrm{~W} \mathrm{~m}^{-2}$ absolutely and $15.2 \%$ relatively for cases, which may not negligible. The strong diurnal changes of heavy aerosol loading in SKYNET Hefei site appear frequently, considerable attention has to be paid to the impact on the 24-h averaged $F$ value calculation when using daily averaged AOP.

Using all selected 196 days' data set, there is an increase trend of absolute biases for 24-h average $F$ calculation with increasing daily mean AOD and decreasing daily mean SSA at $500 \mathrm{~nm}$. The statistical absolute and relative biases for 24-h average $F$ calculation are $0.3 \pm 4.2 \mathrm{~W} \mathrm{~m}^{-2}$ and $11.8 \% \pm 6.6 \%$, respectively. Thus, care must be taken when aiming to obtain accurate radiative transfer calculations in a high pollution region based on measured-retrieved long-term high temporal aerosol data.

Acknowledgements. This research is supported by the Ministry of Science and Technology of China (No. 2013CB955802), the Anhui Provincial Natural Science Foundation (No. 1308085MD53), the National Natural Science Foundation of China (No. 41305022), and the Strategic Priority Research Program of the Chinese Academy of Sciences (XDA05100302). We thank P. Khatri and T. Takamura from Chiba University for their kind help. We appreciate the MODIS (http://modis-land.gsfc.nasa.gov/) and OMI (http://disc.sci.gsfc.nasa.gov/Aura/data-holdings/OMI) teams for supplying the free satellite products over SKYNET Hefei site. We would also like to thank all anonymous reviewers for their constructive and insightful comments.

Edited by: O. Torres

\section{References}

Arola, A., Eck, T. F., Huttunen, J., Lehtinen, K. E. J., Lindfors, A. V., Myhre, G., Smirnov, A., Tripathi, S. N., and Yu, H.: Influence of observed diurnal cycles of aerosol optical depth on aerosol direct radiative effect, Atmos. Chem. Phys., 13, 78957901, doi:10.5194/acp-13-7895-2013, 2013.

Campanelli, M., Nakajima, T., and Olivieri, B.: Determination of the solar calibration constant for a sun-sky radiometer: proposal of an in-situ procedure, Appl. Optics, 43, 651-659, 2004.

Che, H., Zhang, X., Chen, H., Damiri, B., Goloub, P., Li, Z., Zhang, X., Wei, Y., Zhou, H., Dong, F., Li, D., and Zhou, T.: Instrument calibration and aerosol optical depth validation of the China Aerosol Remote Sensing Network, J. Geophys. Res., 114, D03206, doi:10.1029/2008JD011030, 2009.

Che, H., Xia, X., Zhu, J., Li, Z., Dubovik, O., Holben, B., Goloub, P., Chen, H., Estelles, V., Cuevas-Agulló, E., Blarel, L., Wang, H., Zhao, H., Zhang, X., Wang, Y., Sun, J., Tao, R., Zhang, X., and Shi, G.: Column aerosol optical properties and aerosol radiative forcing during a serious haze-fog month over North China Plain in 2013 based on ground-based sunphotometer measurements, Atmos. Chem. Phys., 14, 2125-2138, doi:10.5194/acp-14-2125-2014, 2014.

Christopher, S. A., Wang, J., Ji, Q., and Tsay, S. C.: Estimation of diurnal shortwave dust aerosol radiative forcing during PRIDE, J. Geophys. Res., 108, 8596, doi:10.1029/2002JD002787, 2003.

Halthore, R. N., Crisp, D., Schwartz, S. E., Anderson, G. P., Berk, A., Bonnel, B., Boucher, O., Chang, F. L., Chou, M. D., Clothiaux, E. E., Dubuisson, P., Fomin, B., Fouquart, Y., Freidenreich, S., Gautier, C., Kato, S., Laszlo, I., Li, Z., Mather, J. H., Artemio, P. F., Ramaswamy, V., Ricchiazzi, P., Shiren, Y., Trishchenko, A., and Wiscombe W.: Intercomparison of shortwave radiative transfer codes and measurements, J. Geophys. Res., 110, D11206, doi:10.1029/2004JD005293, 2005.

Holben, B. N., Eck, T. F., Slutsker, I., Tanre, D., Buis, J. P., Setzer, A., Vermote, E., Reagan, J. A., Kaufman, Y. J., Nakajima, T., Lavenu, F., Jankowiak, I., and Smirnov, A.: AERONET - a federated instrument network and data archive for aerosol characterization, Remote Sens. Environ., 66, 1-16, 1998.

IPCC: Climate Change 2013: The physical science basis, in: Contribution of Working Group I to the Fifth Assessment Report of the Intergovernmental Panel on Climate Change, edited by: Stocker, T. F., Qin, D., Plattner, G.-K., Tignor, M., Allen, S. K., Boschung, J., Nauels, A., Xia, Y., Bex, V., and Midgley P. M., Cambridge University Press, Cambridge, UK and New York, USA, 2013.

Khatri, P. and Takamura, T.: An algorithm to screen cloud-affected data for sky radiometer data analysis, J. Meteorol. Soc. Jpn., 87, 189-204, 2009.

Kassianov, E., Barnard, J., Pekour, M., Berg, L. K., Michalsky, J., Lantz, K., and Hodges, G.: Do diurnal aerosol changes affect daily average radiative forcing?, Geophys. Res. Lett., 40, 32653269, doi:10.1002/grl.50567, 2013.

Li, Z., Xia, X., Cribb, M., Mi, W., Holben, B., Wang, P., Chen, H., Tsay, S. C., Eck, T. F., Zhao, F., Dutton, E. G., and Dickerson, R. E.: Aerosol optical properties and their radiative effects in northern China, J. Geophys. Res., 112, D22S01, doi:10.1029/2006JD007382, 2007.

Li, Z., Lee, K. H., Wang, Y., Xin, J., and Hao, W.: First observation-based estimates of cloud-free aerosol radiative 
forcing across China, J. Geophys. Res., 115, D00K18, doi:10.1029/2009JD013306, 2010.

McComiskey, A., Schwartz, S. E., Schmid, B., Guan, H., Lewis, E. R., Ricchiazzi, P., and Ogren, J. A.: Direct aerosol forcing: calculation from observables and sensitivities to inputs, J. Geophys. Res., 113, D09202, doi:10.1029/2007JD009170, 2008.

McPeters, R., Kroon, M., Labow, G., Brinksma, E., Balis, D., Petropavlovskikh, I., Veefkind, J. P., Bhartia, P. K., and Levelt, P. F.: Validation of the Aura Ozone Monitoring Instrument total column ozone product, J. Geophys. Res., 113, D15S14, doi:10.1029/2007JD008802, 2008.

Nakajima, T., Sekiguchi, M., Takemura, T., Uno, I., Higurashi, A., Kim, D., Sohn, B. J., Oh, S. N., Nakajima, T. Y., Ohta, S., Okada, I., Takamura, T., and Kawamoto, K.: Significance of direct and indirect radiative forcings of aerosols in the East China Sea region, J. Geophys. Res., 108, 8658, doi:10.1029/2002JD003261, 2003.

Nakajima, T., Yoon, S. C., Ramanathan, V., Shi, G., Takemura, T., Higurashi, A., Takamura, T., Aoki, K., Sohn, B. J., Kim, S. W., Tsuruta, H., Sugimoto, N., Shimizu, A., Tanimoto, H., Sawa, Y., Lin, N. H., Lee, C. T., Goto, D., and Schutgens, N.: Overview of the ABC EAREX 2005 regional experiment and a study of the aerosol direct radiative forcing in East Asia, J. Geophys. Res., 112, D24S91, doi:10.1029/2007JD009009, 2007.

Ricchiazzi, P., Yang, S., Gautier, C., and Sowle, D.: SBDART: a research and teaching software tool for plane-parallel radiative transfer in the Earth's atmosphere, B. Am. Meteorol. Soc., 79, 2101-2114, 1998.
Schaaf, C. B., Liu, J., Gao, F., and Strahler, A. H.: MODIS albedo and reflectance anisotropy products from Aqua and Terra, in: Land Remote Sensing and Global Environmental Change: NASA's Earth Observing System and the Science of ASTER and MODIS, Remote Sensing and Digital Image, Proc. Ser., Vol. 11, edited by: Ramachandran, B., Justice, C., and Abrams, M., Springer-Verlag, 873 pp., 2011.

Ulaby, F. T., Moore, R. K., and Fung, A. K.: Fundamentals and Radiometry, Microwave Remote Sensing: Active and Passive, vol. I, Artech House, Norwood, Mass., 456 pp., 1986.

Wang, Z., Liu, D., Wang, Z., Wang, Y., Khatri, P., Zhou, J., Takamura, T., and Shi, G.: Seasonal characteristics of aerosol optical properties at the SKYNET Hefei site $\left(31.90^{\circ} \mathrm{N}, 117.17^{\circ} \mathrm{E}\right)$ from 2007 to 2013, J. Geophys. Res.-Atmos., 119, 6128-6139, doi:10.1002/2014JD021500, 2014.

Westwater, R.: The accuracy of water vapor and cloud liquid determination by dual-frequency ground-based microwave radiometry, Radio. Sci., 13, 677-685, 1978.

Xia, X., Li, Z., Holben, B., Wang, P., Eck, T., Chen, H., Cribb, M., and Zhao, Y.: Aerosol optical properties and radiative effects in the Yangtze Delta region of China, J. Geophys. Res., 112, D22S12, doi:10.1029/2007JD008859, 2007.

Zhou, J., Yu, G., Jin, C., Qi, F., Liu, D., Hu, H., Gong, Z., Shi, G., Nakajima, T., and Takamura, T.: Lidar observations of Asian dust over Hefei, China, in spring 2000, J. Geophys. Res., 107 AAC5.1-AAC5.8, doi:10.1029/2001JD000802, 2002. 